\title{
FIRST DOCUMENTED NESTING RECORD AND STATUS OF THE WILLOW FLYCATCHER IN MANITOBA
}

KEN D. DE SMET and MICHAEL P. CONRAD, Manitoba Department of Natural Resources, Box 14, 1495 St. James Street, Winnipeg, Manibota R3H OW9

Until recently, the Willow Flycatcher and Alder Flycatcher were considered as western and eastern forms of the "Traill's Flycatcher. Extensive field studies by Stein identified consistent song, habitat and nest site differences between these forms and prompted the American Ornithologists' Union Checklist committee to recognize the existence of two distinct species. ${ }^{9} 1$
Alder and Willow flycatchers can only be reliably identified in the field by their vocalizations. The typical song of the Alder Flycatcher is a harsh, throaty rrreebeep' or fee-bee;', often shortened to rreep, with a rising inflection. ${ }^{13}$ Alder's call is a rather low, flat pip, peep or tip; sometimes likened to the distant call of Picoides woodpeckers or the kip call of

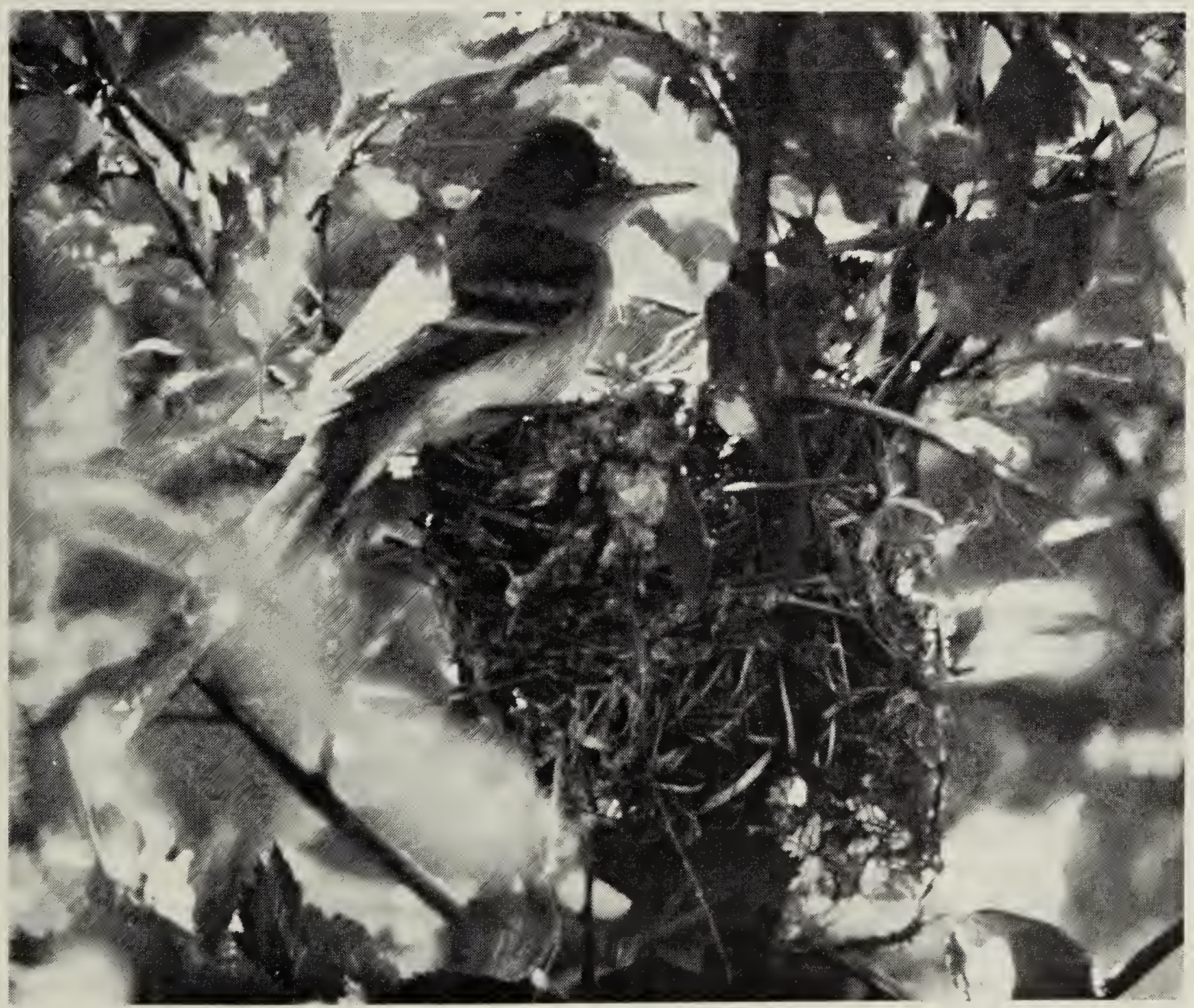

Willow Flycatcher on nest

Ken de Smet 
the Western Kingbird. ${ }^{9} 13$ Taylor noted that adults occasionally utter an emphatic bew, similar to the ending of the Willow Flycatcher song. ${ }^{11}$ The Willow Flycatcher's song, also harsh and throaty, is interpreted fitz'-bew or vitz'-bew. ${ }^{9} 13$ Here the accents is more on the first syllable and the song seems to drop slightly in pitch. The typical call of the Willow is a dry whit, usually with a strong wh or hw sound. ${ }^{13}$

Morphological and habitat differences between the two species are less distinct. Willow Flycatchers tend to have a longer bill, shorter and more rounded wings and are slightly paler, with an olive-colored back that is more grayish or brown than that of the Alder Flycatcher. ${ }^{5} 89$ The eyerings of Willows average less conspicuous than those of Alders, but most Willows have at least a hint of a whitish eye-ring around the posterior one-half to one-third of the eye. ${ }^{13}$ The Willow Flycatcher is typically found in riparian habitat in grassland areas, whereas the Alder Flycatcher prefers riparian edge habitat in wooded areas. ${ }^{9} 15$ The Willow Flycatcher constructs a neat and compact "Cottony" nest, whereas the Alder Flycatcher builds a bulky and more ragged nest. ${ }^{5} 15$

The Willow Flycatcher breeds from the southern extremes of Canada south to California, Texas and southwestern United States.' The Alder Flycatcher breeds north of this range from central Alaska and across the boreal forests of Canada south to central British Columbia, northern Michigan, New York, New England and into western Maryland. ${ }^{5}$ The species' ranges overlap and sympatric populations have been recorded in British Columbia, Saskatchewan, Minnesota, Michigan, Wisconsin, Pennsylvania, Maryland and New York. ${ }^{3}{ }^{15}$ In Canada, the Willow Flycatcher has been reported during the breeding season in Nova Scotia, New Brunswick, southwestern Quebec and southern Ontario in the east and from southwestern
Manitoba to southern British Columbia in the west. $^{5}$

Since Alder and Willow flycatchers were placed in separate species in 1973, the Willow Flycatcher has been recorded in only a few sites in southern Manitoba (Table 1). Examination of specimens in the National Museum of Canada by Wayne Neily (pers. comm.) also revealed a specimen from Oak Lake, Manitoba (an adult male; specimen No. 16881) collected on 8 August 1921 that, by coloration and application of Stein's formula of wing length versus bill length, was probably a Willow Flycatcher. ${ }^{9}$ From 1978 to 1982 the species was recorded in five sites in southeastern Manitoba, but since then there has been only one record, probably a migrant, from the southeast (Table 1). Their status in southeastern Manitoba is probably occasional to rare. In southwestern and south central Manitoba, the Willow Flycatcher has been observed at ten sites since 1983 and would best be classified as uncommon. Although it was believed to breed in the province, nesting evidence for the Willow Flycatcher in Manitoba was lacking prior to $1987 .^{7}$

Among the objectives of the Department of Natural Resources (DNR) prior to the 1987 field season was an attempt to find an active Willow Flycatcher nest. Other projects on rare and endangered species in southwestern Manitoba left little time and usually field work was in the wrong habitat for Willow Flycatchers. During June the species was found at two sites (Table 1). The Killarney site was checked where Willow and Alder flycatchers had occurred sympatrically in previous years, but only one silent adult flycatcher was located (Willow or Alder?). By late July singing activity had waned and other studies were being pursued.

During the early afternoon of 22 July a survey was made along the edge of an extensive grassland valley $14 \mathrm{~km} \mathrm{~s}$ of Mel 
ita where Ferruginous Hawks had been seen. The aspen bluffs were being checked for large nests. At several sites, grassy coulees with scattered shrubbery extended from the valley into the surrounding fields. From one of these coulees (nw17-2-26-W1) came an unfamiliar whit call. The call was being uttered by a flycatcher. This bird was observed hawking insects and eventually flying into a hawthorn and chokecherry shrub patch. When it did not immediately come out, the shrub patch was checked and a neatly woven nest was found in a hawthorn. The nest was $1.5 \mathrm{~m}$ up the main stem and contained four nearly naked young.

The dry, open habitat was more suited to a Willow Flycatcher. An hour and a half was spent watching this bird feeding its young. During this time it frequently gave the whit call and occasionally snapped its bill rapidly or issued a chattering call when the nest was approached. The bird gave a minimal response to taped calls of either Willow or Alder flycatchers, but it did appear to respond slightly more to Willow Flycatcher calls. At the same time, an indistinct eye-ring was noted, two whitish wing bars, the sharp contrast between the white throat and grayish breast and sides and a grayish-green head, shoulder, back and tail color. A noticeable creamyyellow colored wrist patch was puzzling since this was not noted in any of the field guides checked.

Another flycatcher was located less than $200 \mathrm{~m}$ from the original nest. Activity centered on a large hawthorn and Saskatoon clump. A nest was located $1.2 \mathrm{~m}$ up the main stem of a hawthorn shrub and it contained only one large young. This nest was photographed. More flycatcher activity was observed near a smaller hawthornSaskatoon clump about $25 \mathrm{~m}$ distant. A third nest was found $1.8 \mathrm{~m}$ up, on the outer branches of a hawthorn; it contained two large young and one addled egg.
That evening taped Willow and Alder flycatcher calls were played in the area. When the calls were played between the second and third nests an adult from the third nest became excited, frequently uttering whit calls. After several repeats of the Willow Flycatcher call this adult began to fly back and forth from clump to clump and eventually uttered a clear fitzbew. Playback of several repetitions of the Alder Flycatcher call immediately after elicited no response. When the Willow Flycatcher call was resumed, the adult once again began responding with whit call notes.

That these were nesting Willow Flycatchers was reaffirmed when at 6:15 a.m. on 6 August at least four Willow Flycatchers were observed giving fitz-bew calls from perches near the nests. All nests were found to be empty; at the first nest an adult became excited at the intrusion, the second nest was also intact but the third nest was torn and may have been predated. The first nest was collected and submitted, with the addled egg that was collected earlier, to the Manitoba Museum of Man and Nature in Winnipeg.

All three of the nests were located in live hawthorn shrubs in patches of dense shrubbery. Nest materials consisted of grass and weed stems, with a cup of fine grasses, plant fibers and feathers. Two of the nests were neatly woven and compact with a fluffy external appearance (from the fluff of weed seeds). The nest that contained only one young was more open and untidy with less fluff. Clutch size in two of the nests corresponds to clutch sizes noted in North Dakota. ${ }^{10}$ The third nest contained only one young but was within $1.5 \mathrm{~m}$ of a Gray Catbird nest containing four young. Catbirds have been known to destroy the eggs of other species.

Although the Willow Flycatcher is con- 


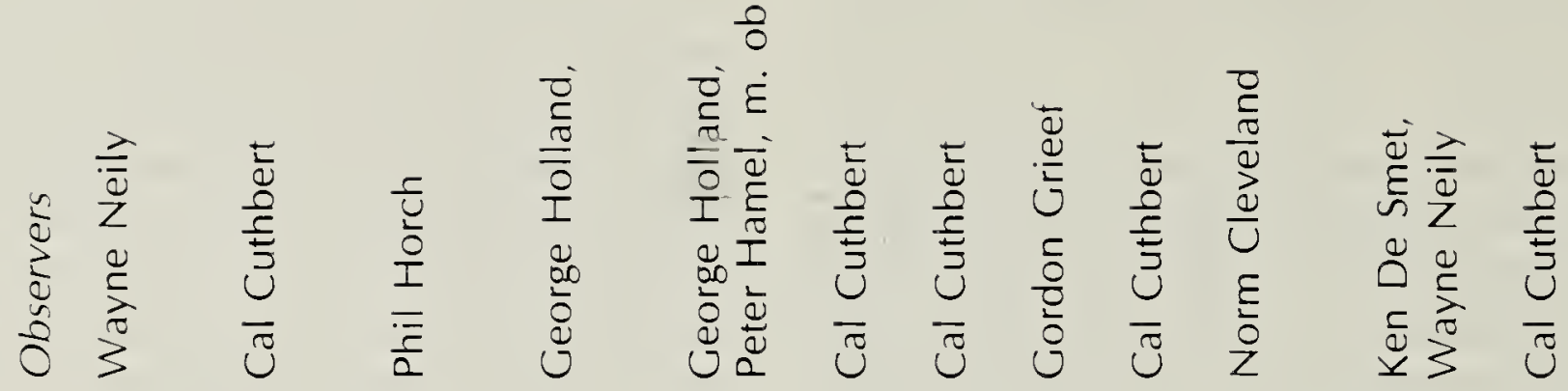<smiles>[AlH2]I</smiles>

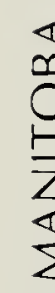

$\stackrel{\infty}{0}$

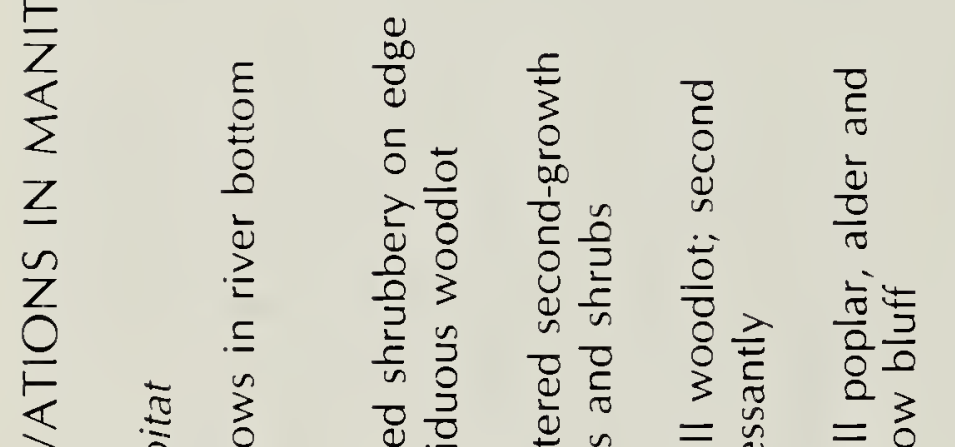

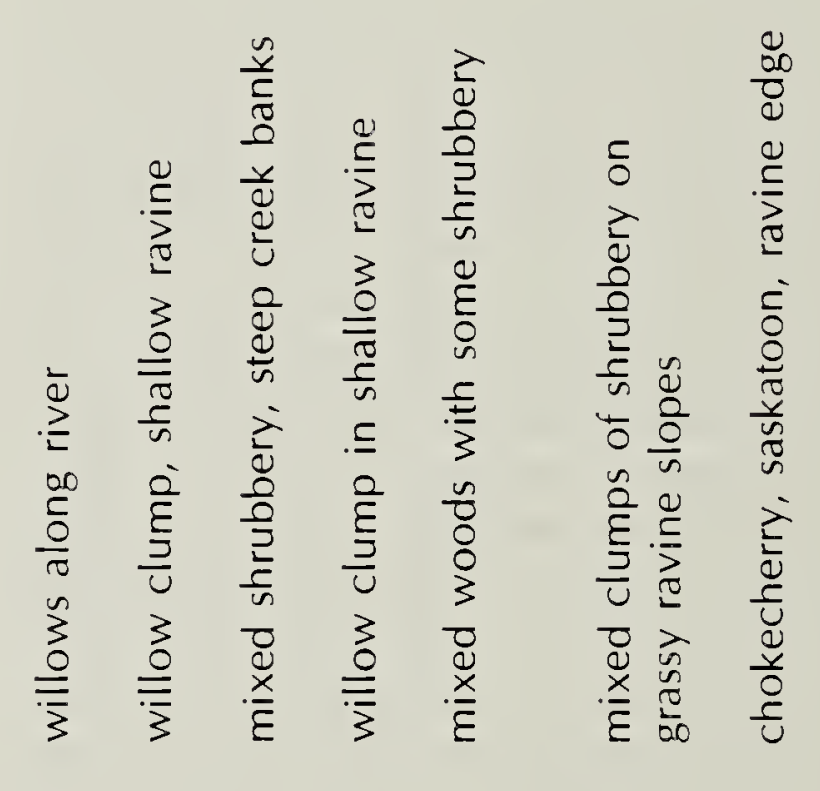

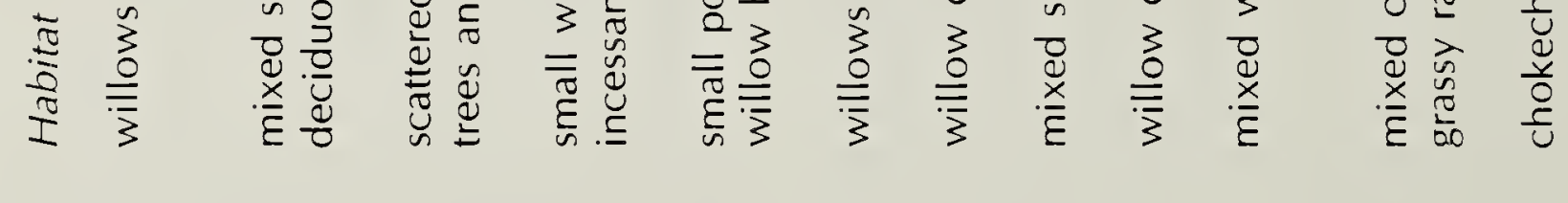

営

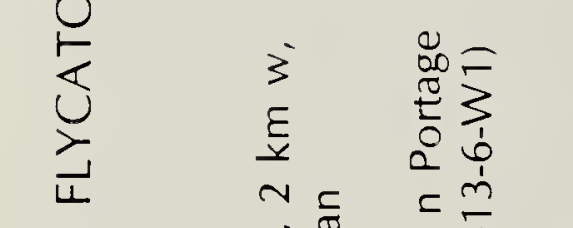

$\stackrel{\bar{\varpi}}{\check{\Perp}}$

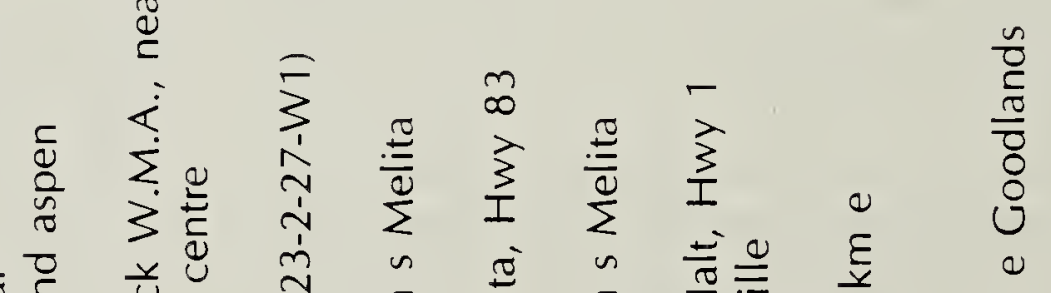

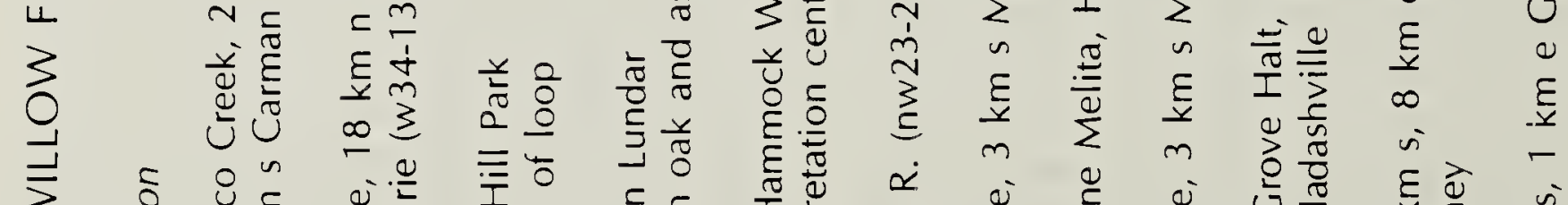

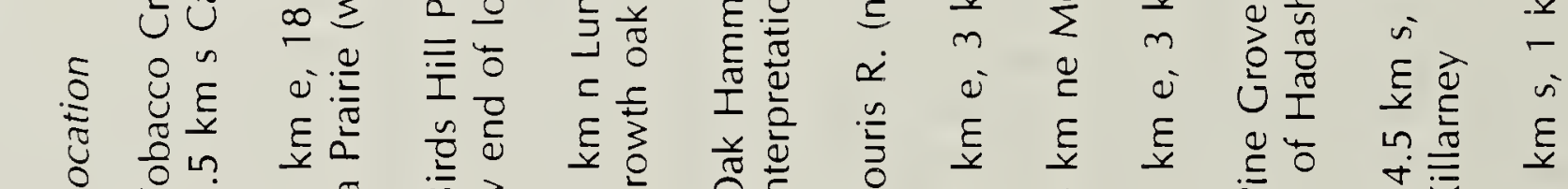

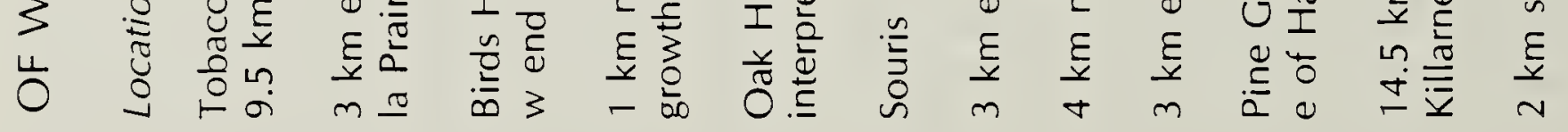

畄

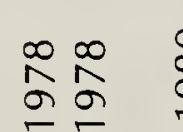
要

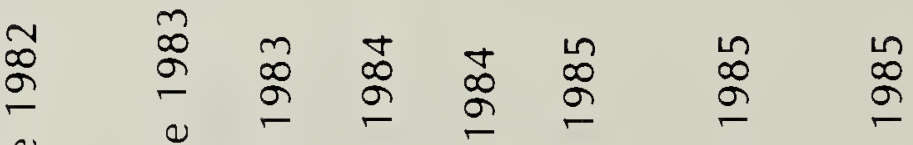

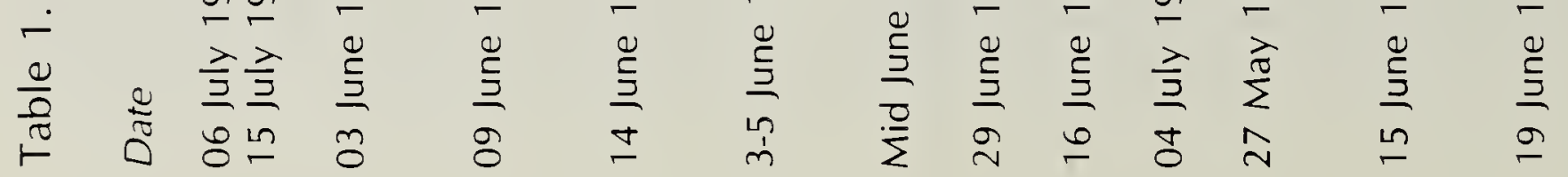




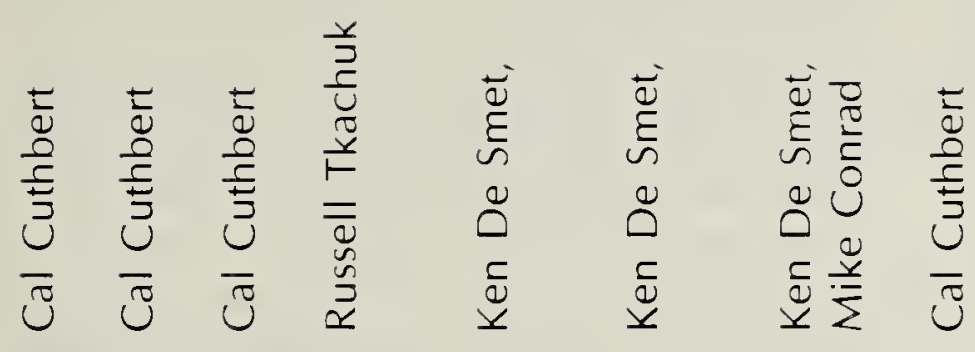

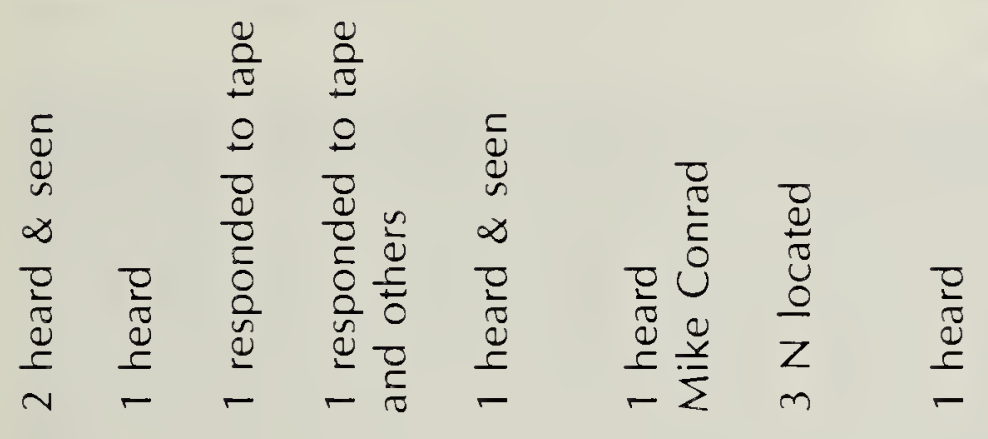

$\begin{array}{lllll} & \\ 0 & \\ 0\end{array}$

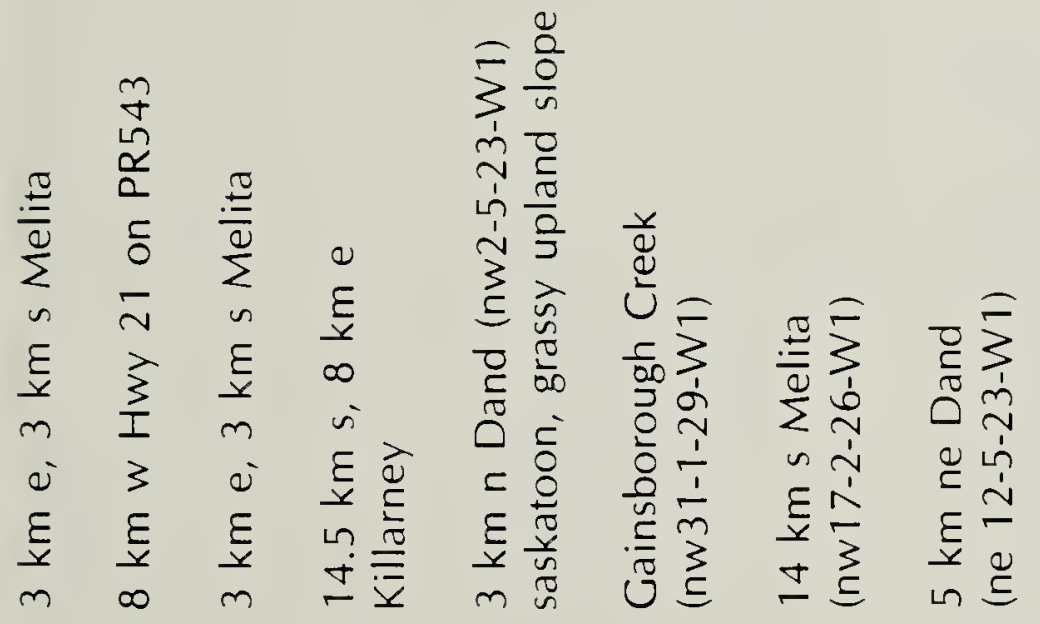

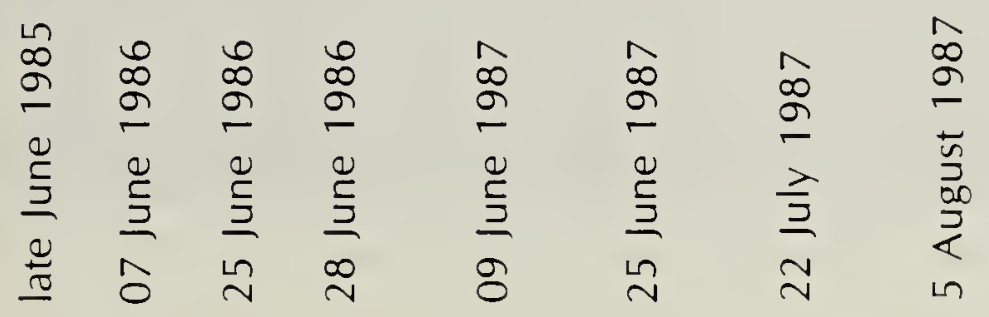

46(3). September 1988 
sidered to be locally common throughout North Dakota and common near the Manitoba border in the Turtle Mountains and Pembina Hills, the Alder Flycatcher has rarely been recorded in the state and is considered a hypothetical breeder. ${ }^{10} 14$ In Manitoba the converse is true. Willow Flycatchers occur sporadically in southwestern and south-central Manitoba, whereas the Alder Flycatcher is locally common throughout southern Manitoba including populations near the North Dakota boundary in the Turtle Mountains and in the extreme southwest. ${ }^{4}{ }^{6}$ Given the northward expansion of Willow Flycatcher populations in other parts of their range, however, the species may eventually become more common throughout much of southern Manitoba.

\section{' AMERICAN ORNITHOLOGISTS' UNION} 1973. Thirty-second supplement to the American Ornithologists' Union checklist of North American birds. Auk 90:411-419.

2 BARLOW, J.C. and W.B. MCGILLIVRAY 1983. Foraging and habitat relationships of the sibling species Willow Flycatcher (Empidonax traillii) and Alder Flycatcher (E. alnormum) in southern Ontario. Can. J. Zool. 61:1510-1516.

${ }^{3}$ CALLIN, E.M. 1980. Birds of the Qu'Appelle, 1857-1979. Spec. Publ. No. 13, Sask. Nat. Hist. Soc., Regina, Sask.

${ }^{4}$ DE SMET, K.D. and C. SMITH 1979. Turtle Mountain resource inventory. Unpubl. rept., Manitoba Parks Branch and Dept. of Nat. Resources, Winnipeg. 193 pp.

${ }^{5}$ GODFREY, W.E. 1986. The birds of Canada, revised edition. Nat Mus. Canada, Ottawa, Ontario. 595 pp.
${ }^{6}$ KNAPTON, R.W. 1979. Birds of the Gainsborough-Lyleton region. Spec. Publ. No. 10, Sask. Nat. Hist. Soc., Regina, Sask.

7 MANITOBA AVIAN RESEARCH COMMITTEE 1986. Field checklist of the birds of Manitoba. Man. Mus. of Man and Nature, Winnipeg.

${ }^{8}$ PHILLIPS, A.R., M.A. HOWE and W.E. LANYON 1966. Identification of the flycatchers of eastern North America, with special emphasis on the genus Empidonax. Bird Banding 37:153- 171.

${ }^{9}$ STEIN, R.C. 1963. Isolating mechanisms between populations of Traill's Flycatchers. Proc. Amer. Phil. Soc. 107:21-50.

10 STEWART, R.F. 1975. Breeding birds of North Dakota. Tri-College Center for Environ. Studies, Fargo, N.D.

11 TAYLOR, P.T. 1983. Wings along the Winnipeg. Eco Series No. 2, Man. Natur. Soc. Winnipeg, Manitoba. 216 pp.

12 TERRES, J.K. 1983. The Audubon Society Encyclopedia of North American birds. Alfred A. Knopf, N.Y. 1109 pp.

${ }^{13}$ WHITNEY, B. and K. KAUFMAN 1986. The Empidonax challenge. Part III: "Traill's" Flycatcher: the Alder Willow problem. Birding 18(3):153-159.

14 ZIMMER, K.J. 1979. A birder's guide to North Dakota. L \& P Press, Denver, Colorado. 114 pp.

15 ZINK, R.M. and B.A. FALL 1981. Breeding distribution, song and habitat of the Alder Flycatcher and Willow Flycatcher in Minnesota. Loon 53:208-214. 